\title{
A PRELIMINARY ASSESSMENT OF THE GEOTHERMAL RESOURCE POTENTIAL OF THE YUMA AREA, ARIZONA
}

\author{
by \\ Claudia Stone \\ Arizona Geological Survey \\ Open-File Report 81-04 \\ February 1981
}

\author{
Arizona Geological Survey \\ 416 W. Congress, Suite \#100, Tucson, Arizona 85701
}

Funded by the U.S. Department of Energy

Contract Number DE-FC07-79ID12009

This report is preliminary and has not been edited or reviewed for conformity with Arizona Geological Survey standards 

Introduction: The area examined in this report is located in the extreme southwestern corner of Arizona, principally in the Sonoran Desert subprovince of the southern Basin and Range province. A very small portion of this corner of Arizona lies within the Salton Trough subprovince, a deep sediment-filled structural depression that trends northwest through Mexico, Arizona, and California (Fig. 1).

At least a dozen geothermal anomalies have been identified in the Salton Trough (Elders, 1979). The geothermal anomalies are generally located above segments of the East Pacific Rise, an oceanic spreading

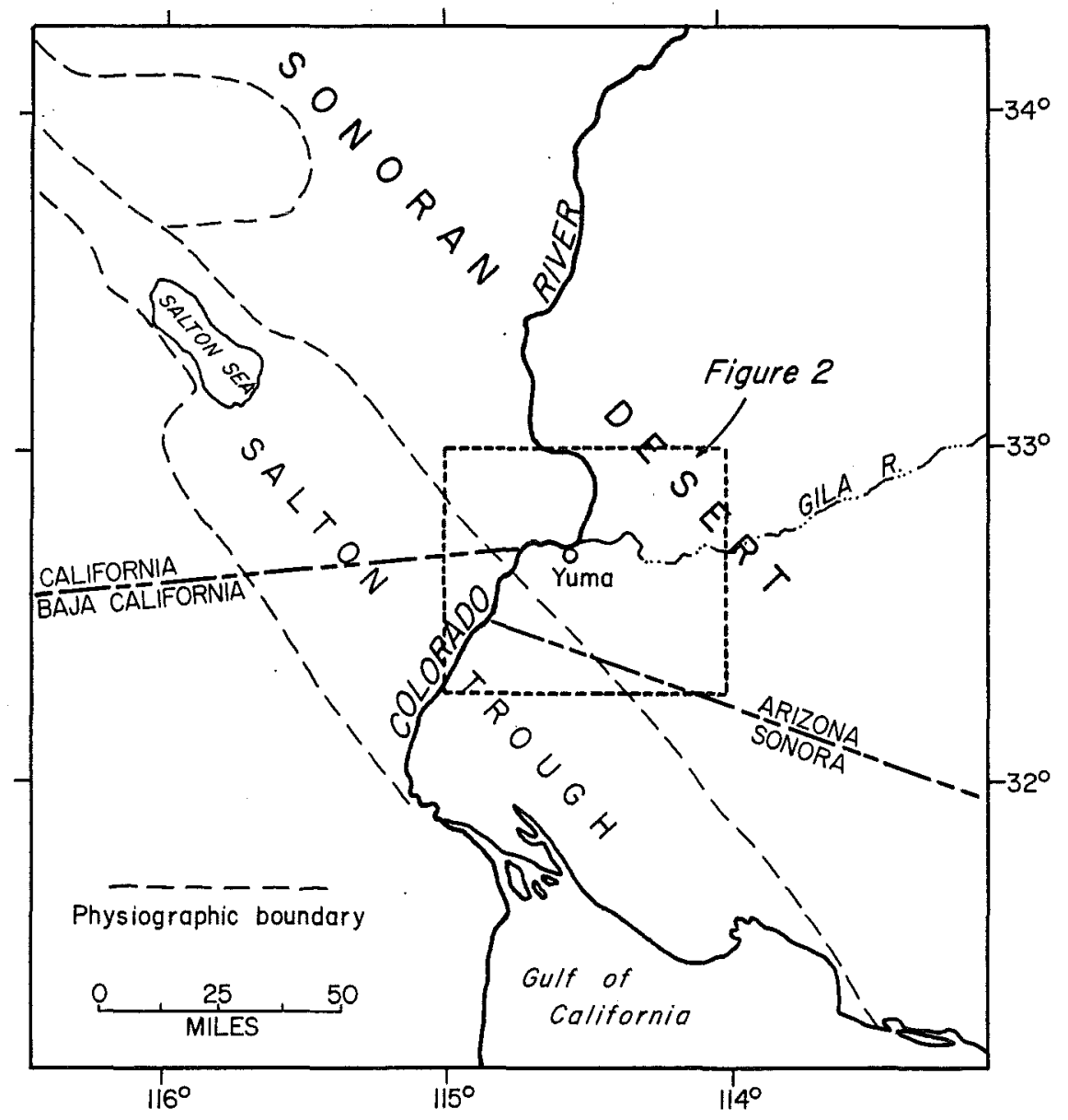

Fig. 1. General location map (after 0lmsted and others, 1973) 
center that extends up the Gulf of California and beneath its landward extension, the Salton Trough. The region is interpreted as a complex, transitional plate boundary that takes up stress created by two different tectonic regimes: spreading at the East Pacific Rise and transform motion along the San Andreas fault system as the Pacific plate moves northwestward. As a result of this continuing motion, the Gulf of Ca1ifornia-Salton Trough system is a actively growing rift.

The present-day Salton Trough was created by block faulting followed by subsidence and deltaic deposition from the Colorado River at the head of the Gulf of California. The present apex of the delta forms a low divide between Imperial Valley to the north, in California, and Mexicali Valley to the south, principally in Mexico. Both of these valleys contain the geothermal anomalies that lie within the Salton Trough.

Proximity of the Salton Trough to the Yuma area makes this a favorable exploration target, even though the existence of a spreading-center heat source in this region is not 1ikely. Rather it is expected that the active tectonism of the Salton Trough periodically reactivates fracture permeability in the basement rocks, which allows convective transfer of heat to shallow depths $(<3 \mathrm{~km})$. The thick blanket of thermally insulating basin-fill sediments then permits the accumulation of economicgrade heat energy within drillable depths.

Iand Status. Farming is the single most important industry in the Yuma area. This is due to the rich soil found in the floodplain and deltaic deposits of the Gila and Colorado rivers, and the extensive use of irrigation waters. As a result of its geographic location and his- 
tory, much of the land on the east (Arizona) side of the Colorado River is in private ownership. An even larger area of land to the east and away from the river is held by the U. S. Army. Table I shows the general land status of the region by major controlling group.

Table 1. Land Status of the Yuma Study Area

\begin{tabular}{lcc} 
Owner or Trust Group & Area $\left(\mathrm{km}^{2}\right)$ & Percent \\
\cline { 2 - 3 } Private Ownership & 734.9 & 39 \\
State of Arizona Trust & 114.0 & 6 \\
BLM Resource Lands & 65.3 & 3.5 \\
Military Reservation & 959.6 & 51 \\
Indian Reservations & 4.5 & $<1$ \\
\multicolumn{1}{c}{ TOTAL } & 1878.3 &
\end{tabular}

Previous Work. Early reports on the Yuma area are limited to a soil survey by Holmes (1903) and brief geologic descriptions by Wilson (1931, 1933). Ground-water conditions were described by Johnson (1954) and by Brown, Harshbarger and Thomas (1956). During the 1960s the U. S. Geological Survey conducted extensive geologic, geohydrologic and gecphysical investigations in the area and published the results in a series of Professional Papers. The Professional Papers useful to this geothermal assessment are those by Mattick, Olmsted, and Zohdy (1973) and 01msted, Loeltz, and Ireland (1973).

Recent work includes ground-water maps by Wilkins (1978), a ground-water status report by the Bureau of Reclamation (1978), an 
aeromagnetic interpretation of the Yuma area by Aiken, Wettereuer, and de la Fuente (1980), and an index to mining properties in Yuma County (Keith, 1978). State maps depicting Landsat and Skylab lineaments (Lepley, 1978, 1979), residual Bouguer gravity (Lysonski, Sumner, Aiken, and Schmidt, 1980), and residual aeromagnetics (Aiken and others, 1980) provide regional geophysical coverage of the state. Unpublished work is available in Ph.D. dissertations and M.S. theses from the University of Arizona, Tucson, a power plant siting report by Woodward-McNeil1 \& Associates (1974), and from C. Swanberg (personal commun., 1979). Regional Geologic History. The Yuma region in southwestern Arizona has had a long and complex tectonic history. Anderson and Silver (1979) presented evidence of a northwest-trending dislocation zone, the Mojave-Sonora megashear, that extends from the southern Inyo Mountains, California across the Mojave, Colorado, and Sonoran deserts, into the Sierra Madre Occidental of Sonora, Mexico. This dislocation zone, which may have as much as 700 to $800 \mathrm{~km}$ of left-lateral offset, disrupts two northeast-trending orogenic and magmatic belts of Precambrian age. Anderson and Silver suggested on the basis of available evidence that the major displacement occurred during Late Jurassic. They pointed out that the generally north-trending basins and ranges, which probably formed after mid-Tertiary time, are superposed upon the trace of the megashear.

In Sonora, plutons of Cretaceous age and their associated volcanic equivalents suggested to Anderson and Silver the existence of a magmatic arc that signaled a return to convergent plate margins along western North America during the Cretaceous. 
Rehrig and Heidrick (1976) presented evidence that subduction and magmatism during the Laramide orogeny (75-50 m.y.B.P.) resulted in vertical uplift and northeast- to east-directed compression, which in turn produced a major extensional trend of east-northeast. Following a quiet period between 30 and $50 \mathrm{~m} \cdot \mathrm{y} \cdot \mathrm{B} . P$. they concluded that subduction ceased and a tensional regime began that reoriented the stress field to north-northwest. As trench destruction migrated northwestward along western North America during the late Tertiary, the San Andreas transform fault system developed. They pointed out that mid- to lateTertiary time (about 30-15 m.y.B.P.) was another period of magmatic activity •

Shafiqullah and others (1980, p. 213) stated that "the peak of midTertiary magmatism was about $32 \mathrm{~m} \cdot \mathrm{y} \cdot, 26 \mathrm{~m} \cdot \mathrm{y} \cdot$, and $21 \mathrm{~m} \cdot \mathrm{y} \cdot$ ago, respectively in western New Mexico, the eastern mountain region of Arizona, and the Sonoran Desert area." They inferred from this a westward drift of magmatism of $30-40 \mathrm{~km}$ per million years.

Keith (1978) presented geochemical evidence for the existence of constant dip-variable depth subduction along western North American between 135 and $80 \mathrm{~m} . \mathrm{y} \cdot$ B.P., after which dip of the Benioff zone began to flatten as a result of increased convergence rates. Variable dipvariable depth subduction is indicated from 80 and $20 \mathrm{~m} \cdot \mathrm{y} \cdot \mathrm{B} . \mathrm{P}$. Flattening of the subducting slab occurred between 30 and $50 \mathrm{~m} \cdot \mathrm{y} \cdot \mathrm{B} \cdot \mathrm{P}$. , followed by a quiescent period of about $10 \mathrm{~m} \cdot \mathrm{y}$. duration during which time little to no magmatic activity occurred in Arizona. Keith (1978) attributed this quiescence to such shallow dip of the subducted slab $\left(<10^{\circ}\right)$ that magmatism was occluded. Renewed magmatic activity about 
$40 \mathrm{~m} \cdot \mathrm{y}$. ago in New Mexico and eastern Arizona indicates that dip of the inclined slab began to steepen, with a marked increase in steepening about $20 \mathrm{~m} \cdot \mathrm{y}$. ago. Magmatism swept back from east to west. Keith attributed the increased slab steepening to slab truncation and detachment, caused by the San Andreas transform system.

The Gulf of California has existed for the last $15 \mathrm{~m} \cdot \mathrm{y}$. The transition to a predominantly transform plate boundary south and west of Yuma in the region of the Gulf of California-Salton Trough has been reflected in rapid tectonic deformation and sedimentation, high heat flow, seismicity, and Quaternary volcanism (Elders, 1979). Rifting continues today.

Area Geology. The area considered in this report is bounded on the northeast side by the northwest-trending Tinajas Altas, Gila, and Laguna mountains. The west and southwest sides are defined by the Colorado River and the international boundary with Mexico, respectively (Fig. 2)

The Yuma area is geologically diverse. It is made up of low, rugged northwest-trending mountains separated by broad, sedimentfilled basins. Extremes in bedrock elevations are the result of both erosional and structural relief, the latter due mainly to continuing subsidence of the Salton Trough. Eberly and Stanley (1978) stated that the Salton Trough tectonics plays a more important role in the Yuma area than does Basin-and-Range tectonics.

The crystalline rocks in this region comprise both igneous and metamorphic rocks. They form a large part of the mountains and underlie the Tertiary and Quaternary rocks throughout the area. The meta- 


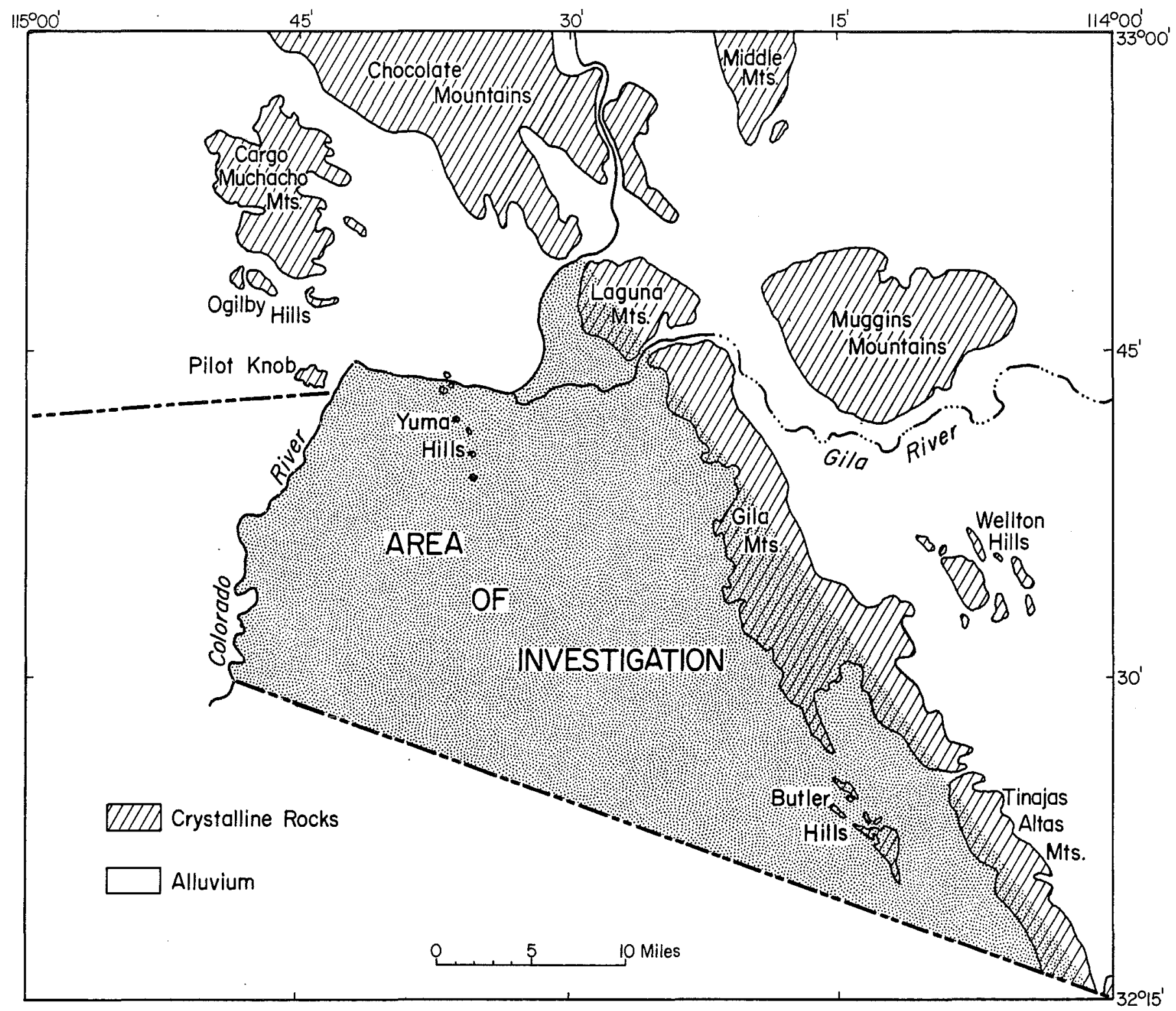

Fig. 2. Index map of the area of investigation, Yuma, Arizona

morphic rocks range from weakly metamorphosed volcanic and sedimentary rocks to strongly metamorphosed schist and gneiss. Quartz monzonite and granite are the most extensive plutonic rocks. 0lmsted and others (1973, p. H32) stated that the porphyritic quartz monzonite "grades into porphyritic granite and has been found in almost all wells that penetrate the pre-Tertiary crystalline rocks in the Yuma area." 
The principal mountains are the Tinajas Altas, Gila, Butler and Laguna mountains in Arizona and the Cargo Muchacho and Chocolate mountains in California (Fig. 2). In Arizona, all but the Laguna range comprise predominantly crystalline rocks: granite, gneiss, and schist (Wilson, Moore, and Cooper, 1969). The Laguna Mountains are principally nonmarine sedimentary rocks of Tertiary age. In California, the Cargo Muchacho Mountains are composed of pre-Tertiary crystalline rocks; The Chocolate Mountains, of Tertiary volcanics (01msted and others, 1973).

A geomorphic land-form classification for the Yuma area was devised by 0lmsted and others (1973). Table 2 is a summary, in decreasing age, of the subareas present in the study area.

Sediments started filling the Fortuna and San Luis basins in early Tertiary time. Olmsted and others (1973) labeled the first four sedimentary units (Fig. 3) as "poorly water-bearing rocks of Tertiary age." They considered these units to be the lower part of the ground-water reservoir since the units contain either scant quantities of water or water that is highly mineralized. There are two exceptions, both in the northern part of the area, where good quality water is found in quantity in these units. The principal units containing agricultural and domestic ground water are the older alluvium, younger alluvium and wind-blown sand, which range in age from Pliocene to Holocene. All were deposited after initiation of fault movement along the San Andreas fault system.

The most important of the lower four units is the Bouse Formation, which has only one surface exposure in the Yuma area, about $3.2 \mathrm{~km}$ southeast of Imperial Dam. The Bouse Formation is important because it 
Table 2. Geomorphic Subareas of the Yuma Area (from 0lmsted and others, 1973)

1. Mountains and hills

a. Tinajas Altas Mountains

b. Gila Mountains

c. Laguna Mountains

d. Butler Mountains

e. Vopoki Ridge

f. Yuma Hills

g. Boundary Hills

2. Dissected old river deposits - "Upper Mesa"

3. Dissected piedmont slopes - Gila Mesa

4. Undissected piedmont slopes

a. Davis Plain

b. Fortuna Plain

5. River terraces and mesas - Yuma Mesa

6. Sand dunes - Fortuna Dunes

7. River Valleys
a. South Gila Valley
b. North Gila Valley
c. Bard Valley
d. Yuma Valley

appears to be the shallowest reliable stratigraphic marker in the subsurfiace and it was deposited prior to major strike-slip movement along the San Andreas fault system. The Bouse Formation has been found everywhere in the subsurface of the basins except an area around and immediately south of the town of Yuma where it pinches out against a buried basement high.

Colorado River water is the principal source of all shallow 


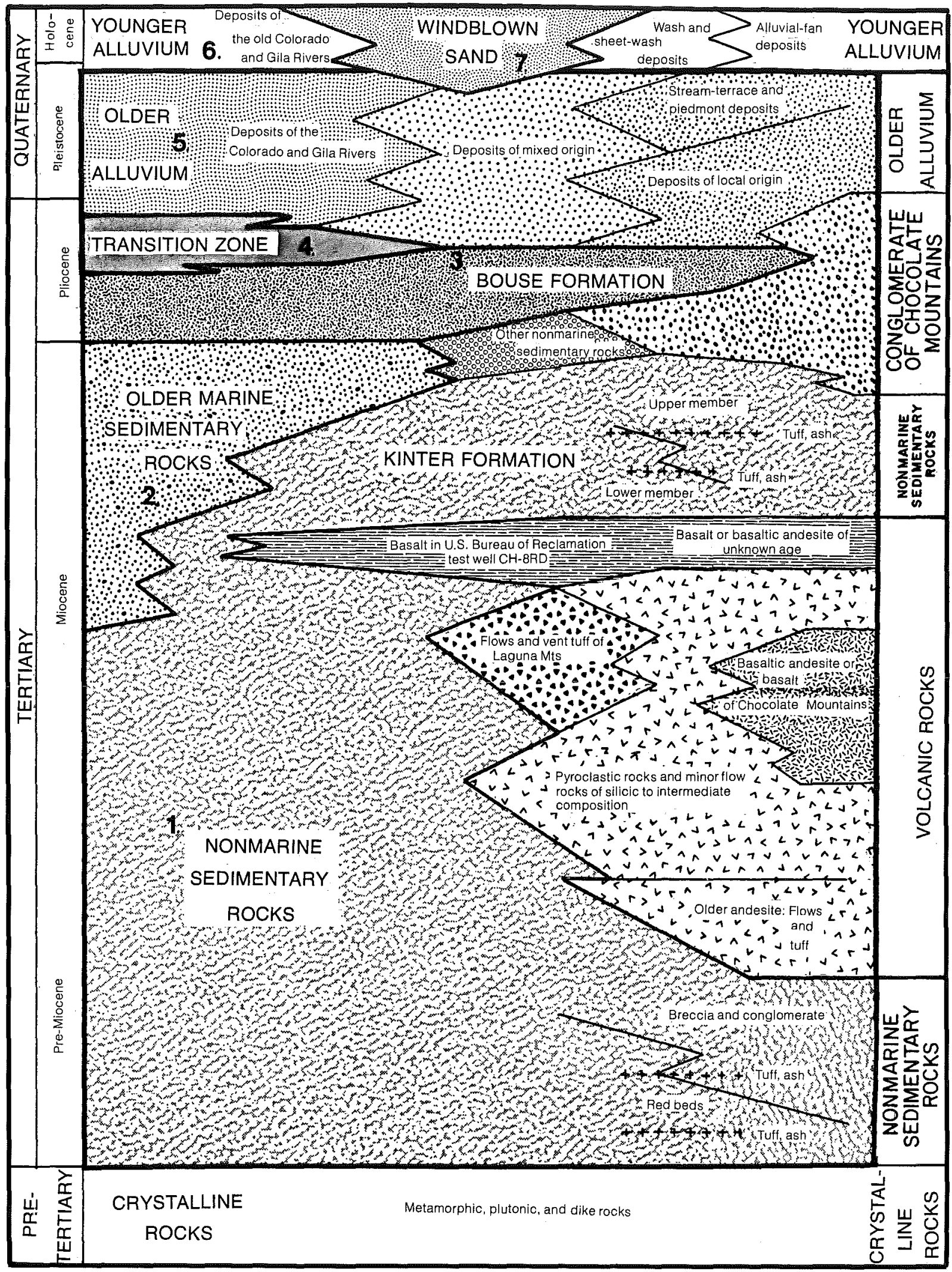

Fig. 3. Stratigraphic column of the Yuma area (from 01msted and others, 1973) 
ground water and ground-water recharge in the Yuma area. Smaller subareas receive significant recharge from the Gila River. Precipitation is about $7.1 \mathrm{~cm}$ per year, but is a very minor source of recharge. Olmsted and others (1973) suggested that the deeper formations may contain some connate water that has never been flushed out. In recent years upstream dams, large-scale pumping from wells, and applications of irrigation waters have created an unstable state of flux in the natural hydrologic cycle in the Yuma area.

Geochemistry. Yuma is a long-standing agricultural community. Large volumes of surface (river) and ground water are applied annually to irrigate crops. Such irrigation has created an artificial groundwater mound that requires pumping from numerous drainage wells to reduce. Olmsted and others (1973) showed that pumping the drainage wells has the desired effect of lowering the water table by causing downward leakage of water from the upper, fine-grained zone into the coarsegravel zone. One result of such large-scale pumping from wells and heavy applications of irrigation water has been to substantially alter the natural quality of ground water by mixing waters from different sources and of different chemical compositions. This mixing has created in historic times an artificial water chemistry that could effectively mask thermal water leaking from a deep geothermal reservoir. Olmsted and others (1973) 1isted additional processes that probably also change the chemical composition of ground water in the Yuma area as a result of irrigation practices. These factors include: (1) concentration by evaporation and evapotranspiration; (2) softening and hardening by ion 
exchange; (3) sulfate reduction; (4) carbonate precipitation; (5) resolution of salts; and (6) oxidation of dissolved organic substances.

Thus it seems unlikely that chemical geothermometers will be of much value in detecting thermal waters leaking from a deep reservoir. This conclusion is substantiated by looking at concentrations of silica in ground water. Silica contents of 153 random samples of ground water from the Yuma area have a mean value of 27.9 milligrams per liter $(\mathrm{mg} / 1)$, with a standard deviation of on $1 \mathrm{y} \pm 0.59$.

Geophysics. Extensive geophysical work was performed by Mattick and others (1973) to determine subsurface bedrock conditions in the region. They carried out seismic reflection and refraction, gravity, aeromagnetic, and electrical surveys. Their work was performed in conjunction with and complimented the surface and near-surface work of Olmsted and others (1973) that identified and interpreted the area geology and hydrology.

Essentially these studies showed that the subsurface comprises several deep basins separated by bedrock "highs" that are faultbounded horst blocks. Maximum depth to basement in the Fortuna basin is $4,900 \mathrm{~m}$; in the San Luis basin, depth to basement is $4,100 \mathrm{~m}$; and in the Yuma trough, it is $1,100 \mathrm{~m}$ (0lmsted, written commun., 1979). The major fault through the area is the northwest-trending Algodonnes fault, inferred to represent the northeast margin of the Salton Trough and to constitute an extension of the San Andreas fault system that is no longer active (Olmsted and others, 1973) (Fig. 4), Other faults through the Yuma area are shorter en-echelon faults that parallel the 


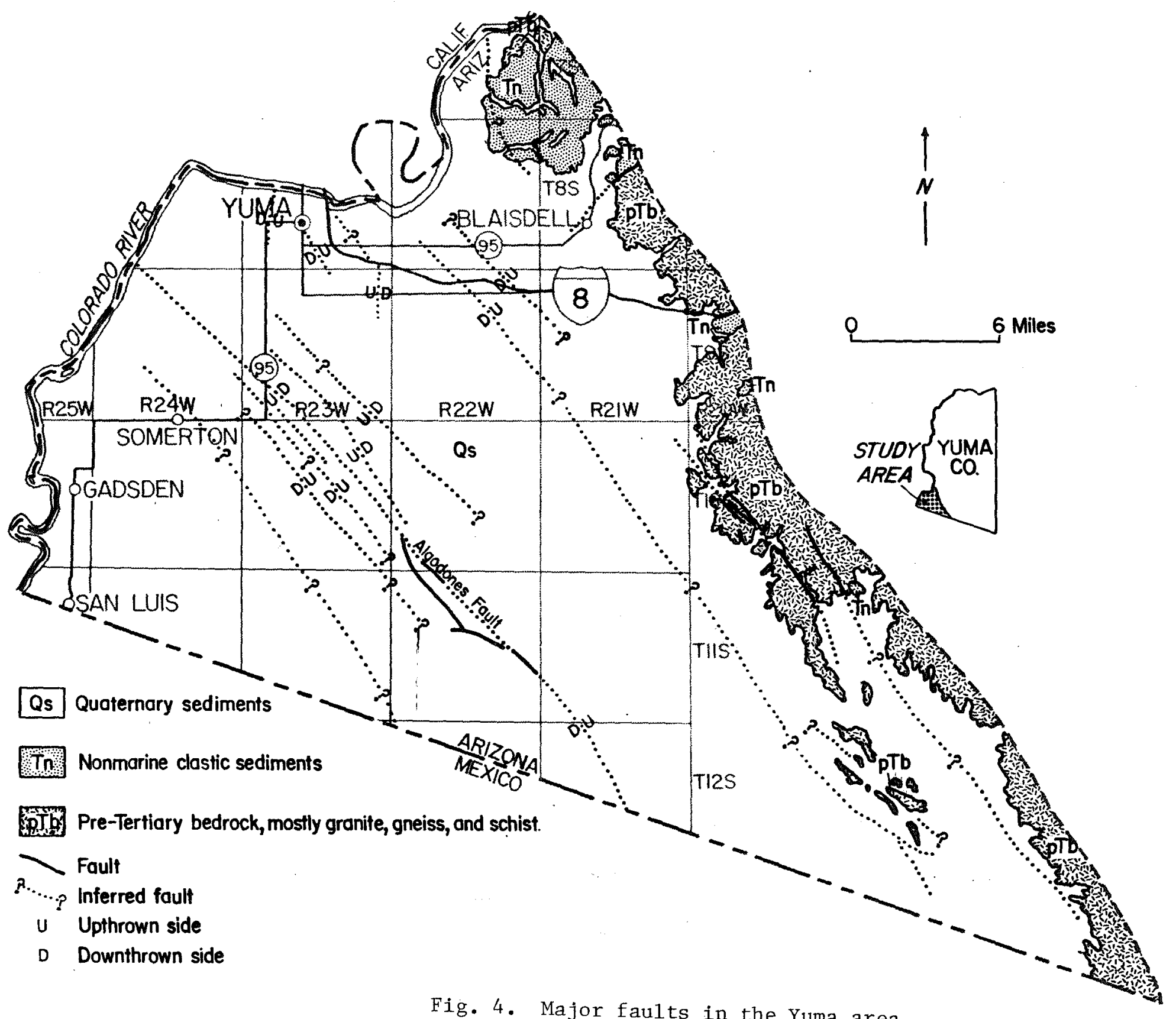

Fig. 4. Major faults in the Yuma area 
Algodonnes fault, and the more north-northwest-trending range-bounding faults of the Laguna, Gila, and Tinajas Altas mountain chain. A number of the subsurface faults were identified through (1) offsets of the Bouse Formation and (2) their observed effect of acting as impermeable ground-water barriers.

More recently, Aiken and others (in press) completed terraincorrected Bouguer gravity maps for the state of Arizona at a scale of 1:250,000. Aeromagnetic data in the Yuma area have been updated by Aiken and others (1980) who merged three sets of pre-existing data by the upward-continuation method. Both gravity and aeromagnetic maps show the same pronounced northwest trends across the region (Figs. 5 and 6). Gravity lows generally reflect the deep basins and gravity highs reflect near-surface or surface exposures of bedrock. A -2 milligal gravity closure occurs over the "Mesa" anomaly of olmsted and others (1973). Drilling and geophysical interpretations showed that the "Mesa" anomaly is a fault-bounded basement high less than $15 \mathrm{~m}$ below the surface.

Two published heat flow measurements in the northern Yuma area, 1.9 and $2.1 \mathrm{HGU}\left(\mu \mathrm{cal} / \mathrm{cm}^{2} \mathrm{sec}\right.$ ) (Sass and others, 1971) are the same as or near the average Basin-and-Range heat flow of $2.1 \mathrm{HFU}$ (Lauchenbruch and Sass, 1977). The higher heat flow is within a "warm anomaly" that was identified by Olmsted and others (1973) as an area of rising warm water (Fig. 7).

Shearer (1979) temperature logged two wells in the southern Yuma area, but was unable to determine the heat flow because he could not 


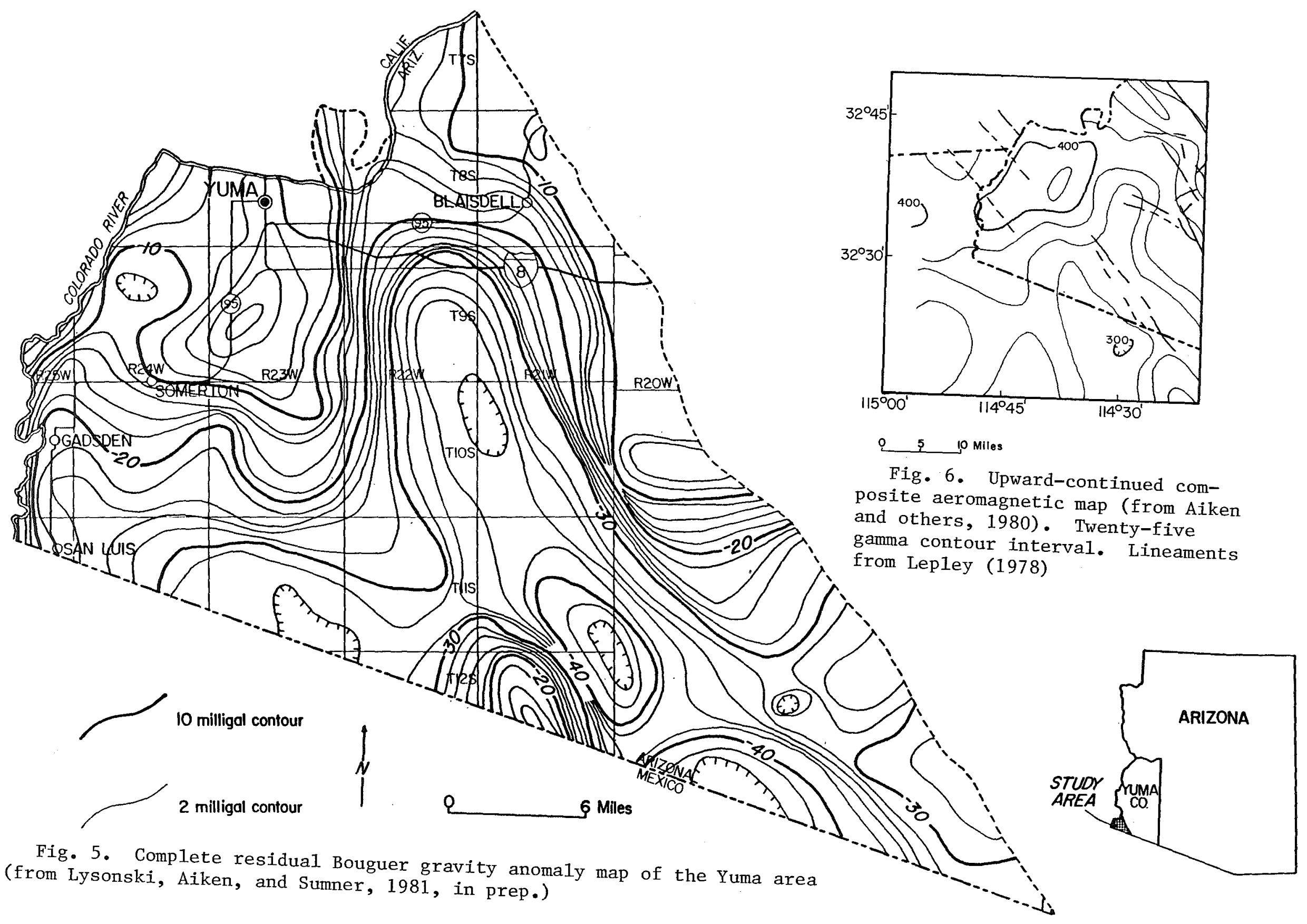


obtain drill cuttings. Because all four thermal gradients (Sass and others, 1971; Shearer, 1979) were measured in deep sediment-filled basins of the same depositional environments, it is probably not unreasonable to apply the thermal conductivities obtained by Sass and others (1971) in the northern basin to the gradients measured by Shearer (1979) in the Fortuna and San Luis basins to the south. These heat flow estimates are shown below.

\begin{tabular}{|c|c|c|c|}
\hline $\begin{array}{l}\text { We11 Names and } \\
\text { Location }\end{array}$ & $\begin{array}{l}\text { Thermal Grad. } \\
{ }^{\circ} \mathrm{C} / \mathrm{km}\end{array}$ & $\begin{array}{l}\text { Thermal Cond. } \\
\mu \mathrm{cal} / \mathrm{cm} \text { sec }\end{array}$ & $\begin{array}{c}\text { Heat Flow Range } \\
\text { HFU }\end{array}$ \\
\hline $\begin{array}{l}\text { Exxon Federal 非1 } \\
8 \mathrm{~S}, 24 \mathrm{~W}, 8\end{array}$ & 39.0 & 5.0 to 5.6 & 2.0 to 2.2 \\
\hline $\begin{array}{l}\mathrm{CH}-28 \mathrm{YM} \\
13 \mathrm{~S}, 20 \mathrm{~W}, 2 \mathrm{abd} 1\end{array}$ & 41.0 & 5.0 to 5.6 & 2.1 to 2.3 \\
\hline
\end{tabular}

(1) from Shearer (1979)

(2) from Sass and others (1971)

The range of these estimated heat flows spans the Basin-and-Range "normal," and the values compare favorably with the two published values. The data suggest that Yuma may be an area of normal Basin and Range heat flow. However, the estimated values are somewhat questionable and all of these heat flows occur along the periphery of the Yuma area. Thus the possibility of a geothermal anomaly occurring in the central area is not necessarily precluded.

Lineaments in the Yuma region (Lepley, 1978) have the same northwest trend that is seen in the gravity, magnetics, and fault traces (Fig. 6). Electric log data and electrical soundings (Mattick and others, 1973) indicate that in the Yuma area the Bouse Formation has a very low average resistivity of $3 \mathrm{ohm}-\mathrm{m}$ and the older marine sedimentary rocks 


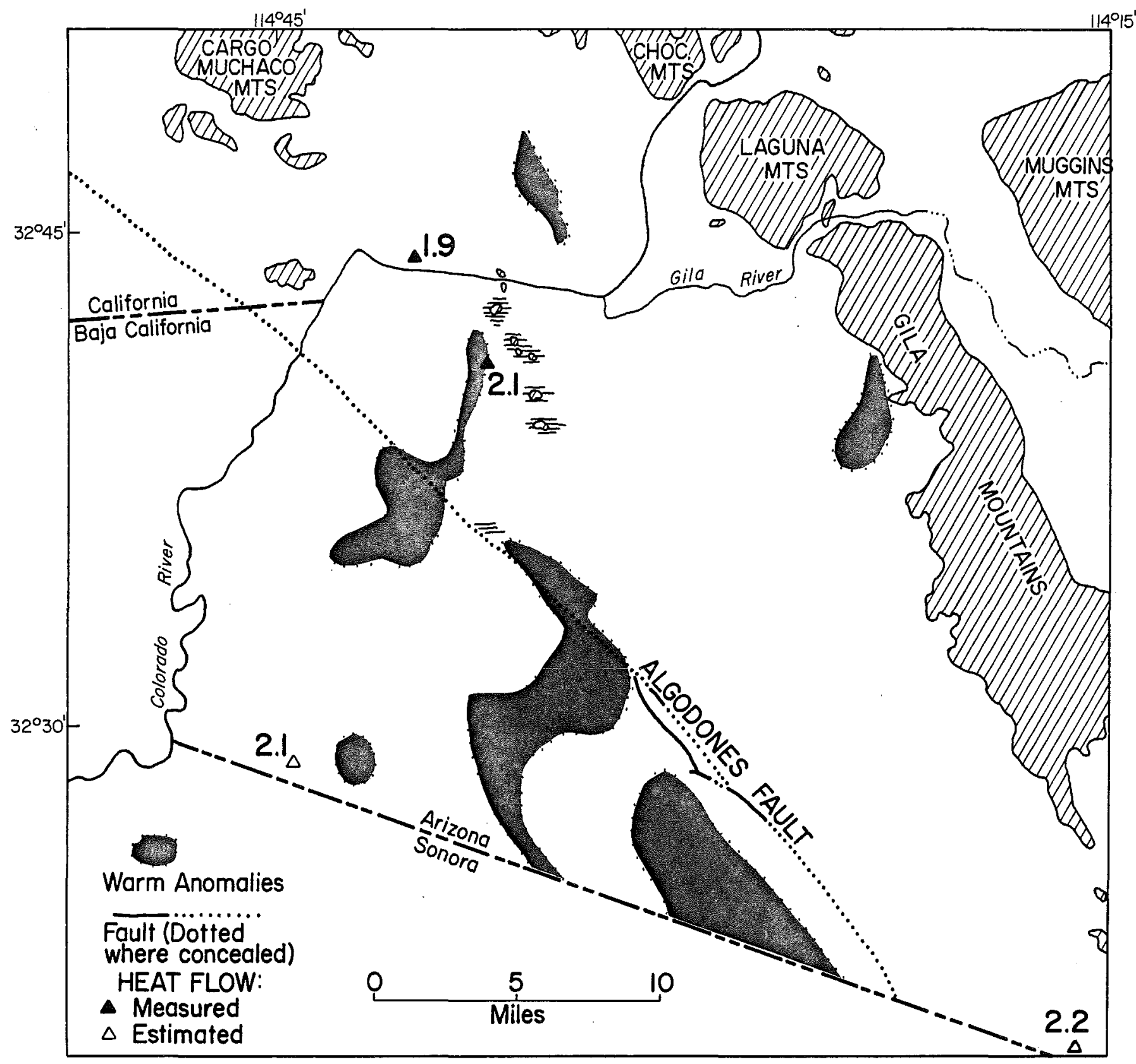

Fig. 7. Warm anomalies (01msted and others, 1973); measured heat flow, solid triangles, (Sass and others, 1971); and estimated heat flow, open triangles, this report 
have an average resistivity of $8 \mathrm{ohm}-\mathrm{m}$. In general, they interpreted the electrical data in terms of formation coarseness, degree of cementation, and water salinity. They only mentioned the possibility of hot water causing or enhancing the high conductivity of the Bouse Formation. Geothermal Gradients. The U. S. Geological Survey open-filed temperature logs of 266 wells in the Yuma area, Arizona and California that were measured during the period 1963-69 (Olmsted, 1980). Most of the wells were shallow $(<100 \mathrm{~m})$ and nearly all of the logs show the effects of seasonal temperature variations and ground-water movement. In addition, Olmsted and others (1973) noted that geothermal gradients, especially on Yuma Mesa, have been greatly modified from their natural conditions due to heavy applications of irrigation water or largescale pumping from wells.

Eleven wells had linear sections of geothermal gradient $>20 \mathrm{~m}$ in length and well diameters $<40 \mathrm{~cm}$, making them somewhat reliable for gradient calculations. Six of the 11 wells had gradients exceeding $30^{\circ} \mathrm{C} / \mathrm{km}$, the Basin-and-Range norm, but generally the data are too sparse to do more than note that the gradients increase to the northwest (Fig. 8). Figure 9 is a similar map of geothermal gradients but it includes, in addition to the previous 11 wells, seven wells from Olmsted (1980) that have shorter linear-gradient segments $(<20 \mathrm{~m})$ or larger diameters $(>40 \mathrm{~cm})$, and thus are less reliable. Nonetheless the gradient contours on this map closely parallel the trace of the Algodonnes fault and other northwest-trending faults. The gradient "high" within the $200^{\circ} \mathrm{C} /$ $\mathrm{km}$ contour coincides with the Mesa basement high and the "Mesa" gravity 


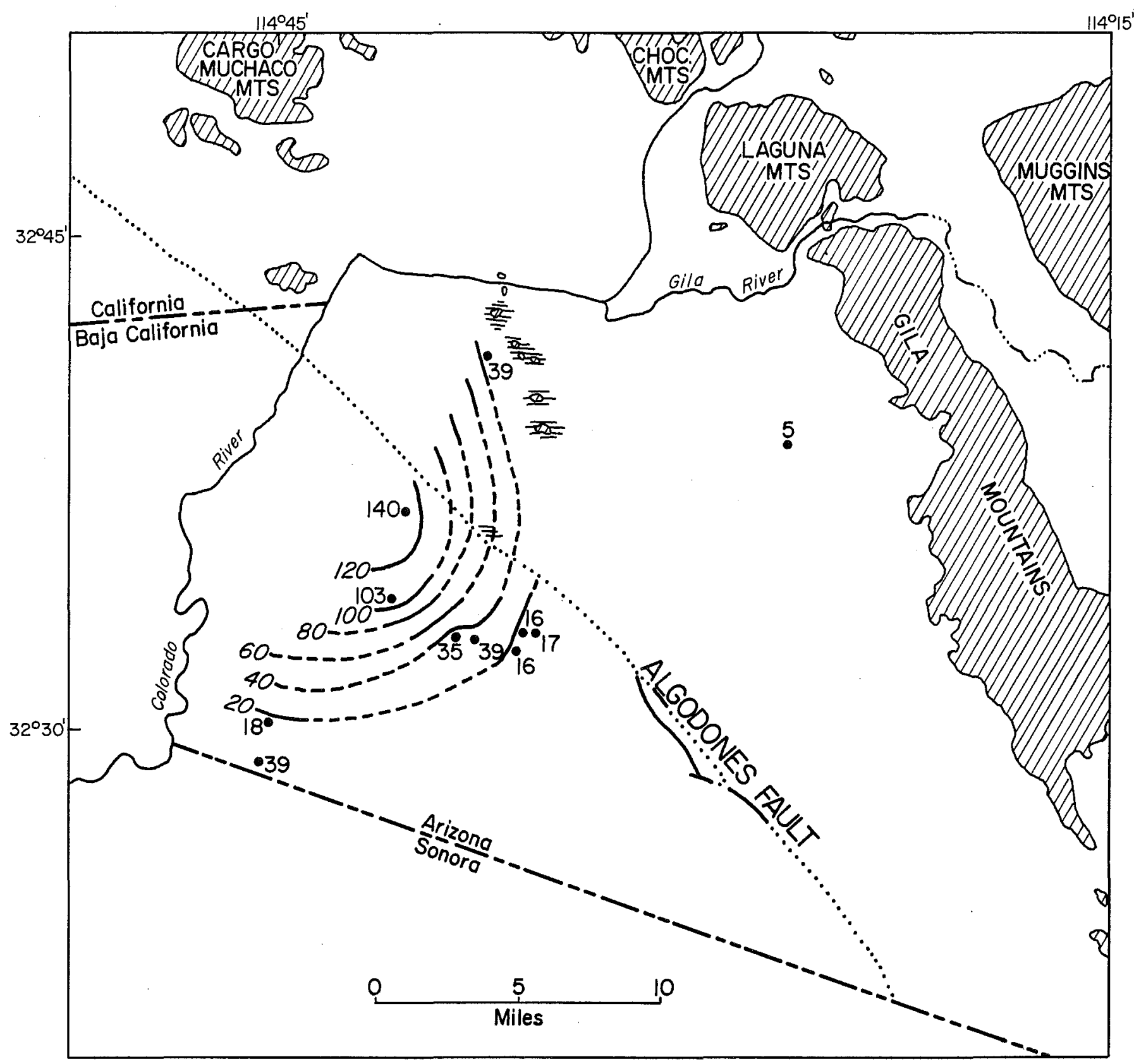

Fig. 8. Measured thermal gradients $\left({ }^{\circ} \mathrm{C} / \mathrm{km}\right)$. from wells with linear gradients greater than $20 \mathrm{~m}$ in length and diameters less than 16 inches 


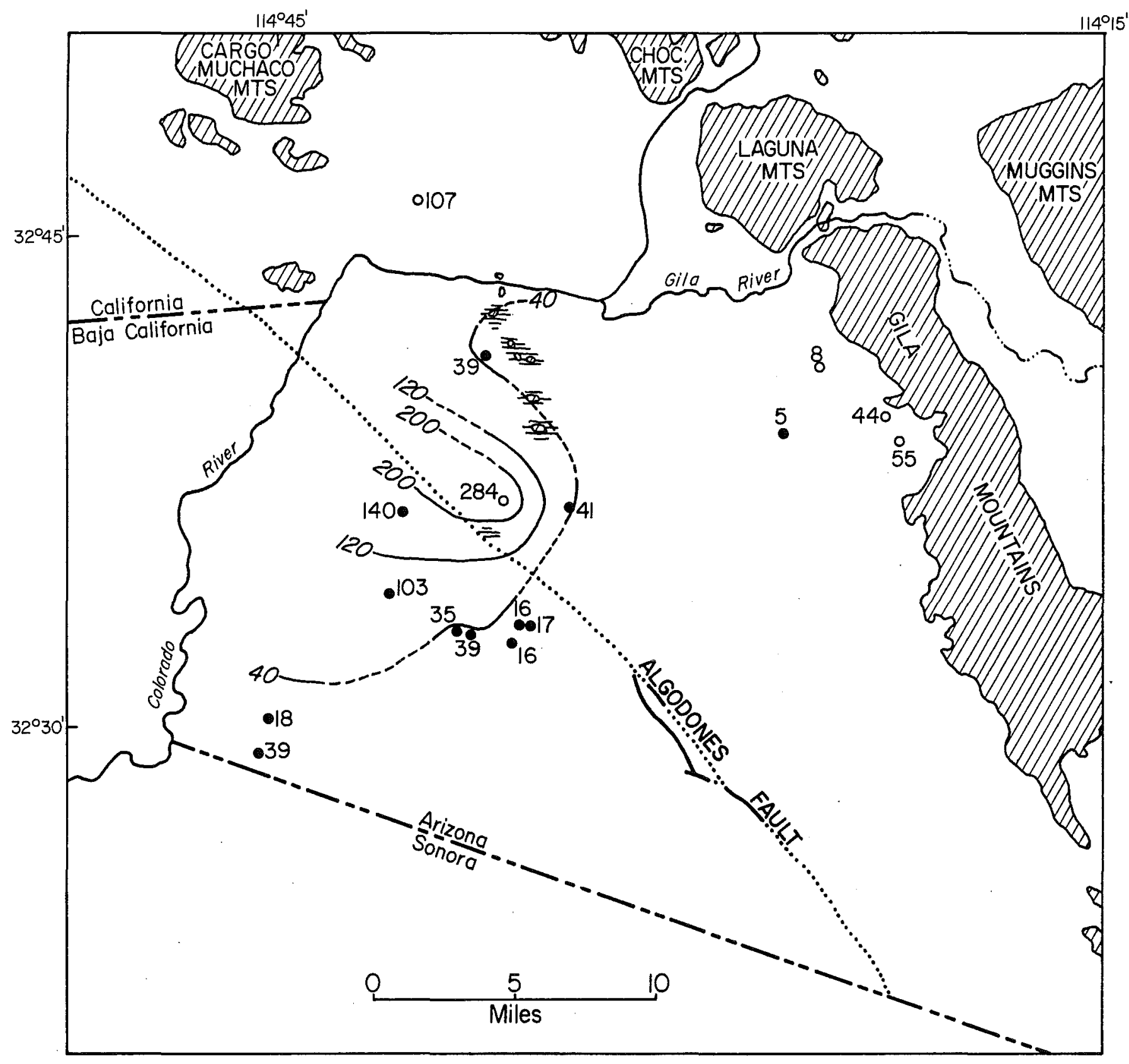

Fig. 9. Measured thermal gradients $\left({ }^{\circ} \mathrm{C} / \mathrm{km}\right)$; closed circles as in Fig. 8; open circles are gradients based on less-reliable well data 
and aeromagnetic anomalies of Mattick and others (1973). It seems probable, however, that the overlap of the geothermal gradient anomaly with the gravity and aeromagnetic anomalies is largely coincidental. The gradient anomaly is interpreted to reflect warm water rising along the northwest-trending faults that were identified by Mattick and others (1973), immediately northeast and southwest of the Mesa basement high. The gravity and aeromagnetic anomalies, on the other hand, are likely a reflection of the bedrock high itself.

Based on well-discharge temperatures, Jones (personal commun., 1979), defined a broad zone of high geothermal gradients $>100^{\circ} \mathrm{C} / \mathrm{km}$ that trends northwest, parallel to the Algodonnes fault. Olmsted and others (1973) contoured ground-water temperatures in the coarse-gravel zone below the water table and identified several areas of anomalously warm temperatures (Fig. 7). They attributed most warm anomalies to warm water rising along faults where the faults act as ground-water barriers. They attributed several broad anomalies, however, including the zone identified by Jones, to the effects of alluvium that is less transmissive than alluvium in surrounding areas. They further suggested that some of the warm anomalies may reflect hot zones in pre-Tertiary crystalline rocks.

An interesting point to note is that the gradient anomaly over the Mesa basement high corresponds closely with one of the fault-controlled warm anomalies identified by 01msted and others (1973) (compare Figs. 7 and 9). This correlation helps confirm the validity of both methods for identifying areas of rising warm water, which in turn may signal a geothermal anomaly. 
Summary. The Yuma area has had a long and complex tectonic history. The most southwesterly corner of the area presently comprises a small segment of the Salton Trough, a deep sediment-filled structural depression. Known geothermal anomalies in the Salton Trough make the Yuma area a favorable exploration target even though spreading-center heat sources are not expected to occur there.

Geological and geophysical investigations reveal that the area is made up of low, rugged northwest-trending mountains separated by deep sediment-filled basins. Relief is a result of both erosional and structural activity. Northwest-trending en-echelon faults bound the range fronts and the basins, and have created several horst blocks (basement "highs") that crop out at or near the surface. The Algodonnes fault is inferred to represent the northeast margin of the Salton Trough and apparently an inactive extension of the San Andreas fault system.

Extensive well-pumping and applications of irrigation waters in recent years have created an unnatural state of flux in the hydrologic regime in the Yuma area.

Gravity and aeromagnetic anomalies trend strongly northwest through the region as do lineaments derived from Landsat and Skylab photos. Electrical resistivity values in the Bouse Formation are exceptionally low, about $3 \mathrm{ohm}-\mathrm{m}$. Heat flow appears to be normal for the Basin and Range province.

Ground-water temperatures indicate zones of rising warm water, with one such "warm" anomaly confirmed by sparse geothermal-gradient data. Conclusions. The geologic setting of deep sediment-filled, faulted, 
and fault-bounded basins bordering an area of active tectonism presents an encouraging target for geothermal exploration. It is possible that active tectonism of the Salton Trough-Gulf of California system periodically reactivates fracture permeability in the basement, allowing convective transfer of heat to shallow depths, and thick insulating basin-fill sediments permit the accumulation of this heat energy. Extensive irrigation and pumping practices have combined in recent years to mix the ground water in the Yuma area to such an extent that variations in chemical composition are useless in detecting geothermal fluids that may be leaking upwards from a deep reservoir.

The strong northwest structural trend through this area is seen in the lineaments and in the gravity and magnetic maps. This trend is a reflection of involvement in the Gulf of California-Salton. Trough system, a transform system that is currently active along two major plate boundaries to the west and southwest of Yuma.

Published and estimated heat flow from the periphery of the area are normal for the Basin and Range province. These values may or may not be indicative of heat flow throughout the entire region.

Above-normal thermal gradients in the area of the Mesa anomaly could be a result of high conductive heat flow (in the range 11 to $14 \mathrm{HFU}$, assuming a thermal conductivity of 5.0 to $5.6 \mu \mathrm{cal} / \mathrm{cm} \mathrm{sec}{ }^{\circ} \mathrm{C}$ that was discussed earlier) or given normal heat flow in the central area, the high gradients could be a result of less-consolidated basin fill in this region than in surrounding areas, resulting in lower thermal conductivity and thus higher thermal gradients. A third explanation is that the gra- 
dients reflect transport of heat to a shallow depth below the surface by a hydrothermal convection system. Rising warm water in this area tends to support the latter explanation.

Low resistivity has been found in the Bouse Formation and older marine sedimentary rocks. However, this evidence is tenuous in terms of geothermal evidence since highly saline connate water, porosity, formation coarseness, and other factors could be the cause of the observed low resistivity, rather than abnormally high temperatures.

Presently the only positive indication of a potential geothermal resource in the Yuma area is the occurrence of an area of high thermal gradients coincident with a fault-bounded horst block and a "warm" anomaly.

A magnetotelluric survey, deep heat-flow holes, and test holes to collect deep uncontaminated water samples for chemical and isotopic analyses would comprise the most valuable exploration program in the Yuma area, in view of what is presently known.

\section{References}

Aiken, C.L.V., Lysonski, J.C., Sumner, J.S., and Hahman, W.R., 1981, A series of 1:250,000 complete residual Bouguer gravity anomaly maps of Arizona: Arizona Geological Society Digest, v. 13, in press.

Aiken, C.L.V., Wettereuer, R.H., and de 1a Fuente, M.F., 1980, A merging of aeromagnetic data sets in southwest Arizona and northwest Mexico and analysis of results: Arizona Geological Society Digest, v. 12, p. 31-44.

Anderson, T.A., and Silver, L.T., 1979, The role of the Mojave-Sonora Megashear in the tectonic evolution of northern Sonora: Geo1. Soc. of America Guidebook-Field Trip No. 27, Geology of Northern Sonora, p. 59-68.

Brown, R.H., Harshbarger, J.W., and Thomas, H.E., 1956, Analysis of basic data concerning ground water in the Yuma area, Arizona: U.S.G.S. 
Open File Report No. 14, 117 p.

Eber1y, L.D., and Stanley, T.B., Jr., 1978, Cenozoic stratigraphy and geologic history of southwestern Arizona: Geol. Soc. America Bull., v. 87 , p. 921-940.

Elders, W.A., 1979, The geological background of the geothermal fields in the Salton Trough, in Elders, W.A., Geology and Geothermics of the Salton Trough, Guidebook 7, GSA annual meeting, San Diego, p. 1-19.

Holmes, J.G., 1903, Soil survey of the Yuma area, Arizona: U.S. Dept. Agri., Field Oper., Bur. Soils, p. 777-791.

Johnson, P.W., 1954, Memorandum on ground water conditions in parts of Tps. 10 and 11 S., Rs. 23 and 24W., Yuma County, Arizona: U.S.G.S. Open File Report No. 41, 5 p.

Keith, Stanley B., 1978, Paleosubduction geometries inferred from Cretaceous and Tertiary magmatic patterns in southwestern North America: Geology, v. 6, p. 516-521.

Keith, Stanton B., 1978, Index of ming properties in Yuma County, Arizona: Bureau of Geology and Mineral Technology Bulletin 192, 185 p.

Lauchenbruch, A.H. and Sass, J.H., 1977, Heat flow in the United States and the thermal regime of the crust: in Heacock, John G., ed., the Earth's Crust, AGU Monograph 20, p. 62 $\overline{6-675 .}$

Lepley, L.K., 1978, Landsat lineament map of Arizona with emphasis on Quaternary fractures, in Low Temperature Geothermal Reservoir Site Evaluation in Arizona, Bureau of Geology and Mineral Technology, Tucson, Arizona, p. 63-91.

1979, 1:500,000 scale Skylab Lineament Map of Arizona with Tectonic Model and Exploration Guide for Geothermal Resources, in Geothermal Reservoir Site Evaluation in Arizona, W.R. Hahman, Sr., ed., Bureau of Geology and Mineral Technology, Tucson, Arizona, p. $92-148$.

Lysonski, J.C., Sumner, J.S., Aiken, C.L.V., and Schmidt, J.S., 1980, The Complete Bouguer Gravity Anomaly Map of Arizona, 1:500,000 scale, Laboratory of Geophysics, University of Arizona, Tucson.

Mattick, R.E., Olmsted, F.H., Zohdy, A.A.R., 1973, Geophysical studies in the Yuma area, Arizona and California: U.S. Geological Survey Professional Paper 486-D.

Olmsted, F.H., 1980, Temperature logs of wells and test wells in the Yuma area, Arizona and California, U.S.G.S. Open-file Report 80-335, $300 \mathrm{p}$.

Olmsted, F.H., Loeltz, O.J. and Irelan, Burdge, 1973, Geohydrology of 
the Yuma area, Arizona and California: U.S. Geological Survey Professional Paper 486-H.

Rehrig, W.H. and Heidrick, T.L., 1976, Regional tectonic stress during Laramide and late Tertiary intrusive periods, Basin and Range province, Arizona, Arizona Geological Society Digest 10, p. 205-228.

Sass, J.H., Lachenbruch, A.H., Munroe, R.J., Green, G.W., and Moses, T.H., Jr., 1971, Heat flow in the Western United States, Jour. Geophys. Research, v. 76, p. 6376-6413.

Shafiqullah, M., Damon, P.E., Lynch, D.J., Reynolds, S.J., Rehrig, W.A., and Raymond, R.H., 1980, K-Ar geochronology and geologic history of southwestern Arizona and adjacent areas, Arizona Geological Society Digest 12, p. 201-260.

Shearer, C.R., 1979, A regional terrestrial heat-flow study in Arizona, Ph.D. dissertation, New Mexico Institute of Mining and Technology, Socorro, $184 \mathrm{p}$.

Swanberg, C.A., 1975, The Mesa Geothermal Anomaly, Imperial Valley, California: a comparison and evaluation of results obtained from surface geophysics and deep drilling, in Proceedings, Second United Nations Symposium on the Development and Use of Geothermal Resources, vol. 2 , p. 1217-1229.

U.S. Bureau of Reclamation, 1978, Ground-water status report, 1977, Yuma area-Arizona, California; U.S.B.R., Yuma Project Office, 20 p. with Appendix.

Wilkins, D.W., 1978, Maps showing ground-water conditions in the Yuma area, Yuma County, Arizona-1975; U.S. Geological Survey, Water Resources Investigations 78-62, Open-File Report.

Wilson, E.D., 1931, New mountains in the Yuma desert, Arizona: Geog. Rev., v. 21, p. 221-228.

Wilson, Eldred D., 1933, Geology and mineral deposits of southern Yuma County, Arizona; Arizona Bureau of Mines Bulletin No. 134, 236 p.

Wilson, E.D., Moore, R.M., and Cooper, J.R., 1969, Geologic Map of Arizona, scale 1:500,000.

Woodward-McNeil1 \& Associates, 1974, Yuma Dual-purpose Nuclear Plant, vol。I and II, 47 p., Appendix A-L. 